\title{
Simulation and sensitivity analysis for heavy linear paraffins production in LAB production Plant
}

\author{
Hajir Karimi ${ }^{1}$, Aboalfazl Askari ${ }^{1}$, Elahe Mansouri ${ }^{2}$ \\ ${ }^{1}$ Yasouj University, Chemical Engineering Department, Yasouj 75918-74831, Iran; \\ ${ }^{2}$ Shiraz University of Technology, Chemical Engineering Department, Iran; \\ "Corresponding author: e-mail: aboalfazl_askari@yahoo.com
}

\begin{abstract}
Linear alkyl benzene (LAB) is vastly utilized for the production of biodegradable detergents and emulsifiers. Predistillation unit is a part of $\mathrm{LAB}$ production plant in which that produced heavy linear paraffins $\left(\mathrm{nC}_{10}-\mathrm{nC}_{13}\right)$. In this study, a mathematical model has been developed for heavy linear paraffins production in distillation columns, which has been solved using a commercial code. The models have been validated by the actual data. The effects of process parameters such as reflux rate, and reflux temperature using Gradient Search technique has been investigated. The sensitivity analysis shows that optimum reflux in columns are achieved.
\end{abstract}

Keywords: LAB plant, pre-distillation unit, columns, sensitivity analysis, commercial code.

\section{INTRODUCTION}

As today's chemical process technologies become more sophisticated, it has become increasingly more difficult to design or optimize chemical processes without any efficient software tools. Process simulation softwares, such as ASPEN PLUS, HYSYS, PRO/II, Petro-SIM, now play a major role in a variety of chemical engineering areas and applications. To fully achievement the capability of such commercial codes, one must have good understanding of the modeling details and any synthesis/analysis tools in order to efficiently perform the simulation and accurately yield the solution to engineering problems. Most simulation packages comprise thermodynamic models and extensive databases to solve the required material and energy balances. Such tools can accurately represent the thermodynamic properties of complex solutions, such as those containing a large quantity and variety of compounds, and they can also use reliable algorithms to describe the main unity operations.

Linear alkyl benzene is vastly utilized for the production of biodegradable detergents and emulsifiers. Synthetic biodegradable detergents, based on utilization of branched alkyl benzene sulfonates, had been showed in the 1940s. The demand for detergents promoted the progress of catalytic dehydrogenation of the heavy linear paraffins to the corresponding olefins. The resulted mono-olefins then react with benzene to product linear alkyl benzenes $(\mathrm{LAB})^{\mathbf{1}-3}$. Kerosene is a main feedstock stream in pre-distillation unit of LAB plant, which products heavy linear paraffins $\left(\mathrm{nC}_{10}-\mathrm{C}_{13}\right)$ stream as middle distillate. For better design of new equipment, the development of new processes and automatic control of pre-distillation unit for the production of higher molecular weight paraffins require efficient simulations programs and accurate analysis. The simulation programs can predict some characteristics and variables of the process, when some other conditions change in the process (the feed concentration or feed flow rate and etc. for instance).

Little information on the simulation and sensitivity analysis of industrial LAB plant rather oil refinery is available in literature ${ }^{4}$. Modeling and simulation of oil refinery processes using simulators such as HyperChem and ASPEN PLUS have been favorably addressed by
Dolganova et al. and Bhutani et al., respectively ${ }^{5-6}$. Analyses of crude distillation system using ASPEN PLUS have been favorably addressed by More et al. ${ }^{7}$. The authors used multi-objective functions for two cases: first without product flow rate constraints, raw-materials and energy cost, and other case was with product flow rate constraints. Yang et al. ${ }^{8}$ studied the reactive distillation process for the synthesis of tert-amyl ethyl ether (TAEE) using Aspen split simulator. From the view point of separating tert-amyl alcohol (TAA), ethanol $(\mathrm{EtOH})$, and water, Aspen split was applied to obtain the design parameters. The performance of the process was analyzed using changeable sensitive variables. Also, Ying et al. ${ }^{9}$ simulated the technological process of dimethyl ether (DME) synthesis on PRO/II platform in similar literature. Askari et al. ${ }^{10}$ simulated industrial catalytic reforming process on HYSYS Refinery platform. In their investigation, the calculated results are in fair agreement with the actual operating data. Also, the effects of process parameters on product properties using Gradient Search technique evaluated. Four continuous biodiesel processes at a constant flow rate designed and simulated in Aspen HYSYS by Ellis et al. ${ }^{11}$. In the latter study, all four processes were capable of producing biodiesel at high purity, heterogeneous and supercritical processes were the least complex and had the smallest number of unit operations. Also, material and energy flow were calculated in each process. Other literature of biodiesel process has been published by Agarwal et al. ${ }^{12}$ using CHEMCAD simulator. In their study, the effects of process parameters using Gradient Search technique have been investigated. No work on simulation and sensitivity analysis of pre-distillation unit has been carried out of LAB Plant for first time. The studies in literatures are related to other chemical industrial processes.

It is necessary to simulate the pre-distillation unit to achieve the best process condition in order to increase the yield of production and decrease costs of energy (i.e., increasing the quantity and quality of product produced and designing unit for an optimum performance along the process flow diagram). Therefore, the purpose of this article is computational simulation as a typical industrial unit for heavy linear paraffin's distillation from kerosene feedstock stream using HYSYS simulator. 
The results are validated by experimental data, which is taken from the pre-distillation unit of LAB plant. It is a key step that the clear-cut feed components are very important for precise purification of distillation. The heart of pre-distillation unit in LAB plant is distillation columns. Finally, the columns are analyzed based on the Gradient Search (GS) technique. In other words, Gradient Search technique is based on sensitivity analysis of design parameters. Therefore, the multi-objective functions are utilized in order to the optimal operating parameters. Sensitivity analysis is used to determine how "sensitive" a model is to changes in the value of the variables of the model and to changes in the structure of the model. Sensitivity analysis allows determining what level of accuracy is necessary for a variable to make the model sufficiently useful and valid. It can be useful for testing the robustness of the results of a model in the presence of uncertainty and increased understanding of the relationships between input and output variables in a system or model.

\section{PROCESS FLOW DESCRIPTION}

An Aspen HYSYS flowsheet of the pre-distillation unit shown in Figure 1. The raw kerosene (that characterized in Tables 1 and 2) from surge drum V-101 is fed into the stripper column T-101 after the heat exchangers E-101 and E-102. The required heat duty for T-101 is provided from Stripper Reboiler E-103. The overhead stream of $\mathrm{T}-101$ is condensed in air cooled type condenser FA-101

Table 1. The feed compositions of pre-distillation unit

\begin{tabular}{|l|c|}
\hline Kerosene Components & Mass [\%] \\
\hline$n-C_{5}$ & 0.0 \\
\hline$n-C_{6}$ & 0.03 \\
\hline$n-C_{7}$ & 0.16 \\
\hline$n-C_{8}$ & 0.39 \\
\hline$n-C_{9}$ & 0.80 \\
\hline$n-C_{10}$ & 1.65 \\
\hline$n-C_{11}$ & 4.96 \\
\hline$n-C_{12}$ & 5.41 \\
\hline$n-C_{13}$ & 4.65 \\
\hline$n-C_{14}$ & 3.89 \\
\hline$n-C_{15}$ & 1.95 \\
\hline$n-C_{16}$ & 0.33 \\
\hline$T N N$ (others) & 75.78 \\
\hline
\end{tabular}

Table 2. Distillated feed of ASTM D86 Assay

\begin{tabular}{|l|l|}
\hline Assay Percent [\%] & $\mathrm{T}\left[{ }^{\circ} \mathrm{C}\right]$ \\
\hline $0.0(\mathrm{BPP})$ & 158.3 \\
\hline 5 & 184.1 \\
\hline 10 & 190.6 \\
\hline 20 & 199.3 \\
\hline 30 & 206.1 \\
\hline 40 & 211.6 \\
\hline 50 & 216.6 \\
\hline 60 & 222 \\
\hline 70 & 227 \\
\hline 80 & 234.9 \\
\hline 90 & 244.3 \\
\hline 95 & 251 \\
\hline $100(\mathrm{FBP})$ & 259.9 \\
\hline
\end{tabular}

and collected in the Stripper Receiver V-102. A part of collected liquid pumped to stripper column as reflux and the rest leave the unit after cooling in cooler E-104. The bottom product fed to the rerun column T-102. The required heat duty for this column is provided from Stripper Reboiler E-105. The overhead stream of T-102 is condensed in air cooled type condenser FA-102 and collected in the Stripper Receiver V-103. Finally, collected liquid in the V-103 is split into two streams by the splitter TEE-103; one is pumped to rerun column as reflux and the other leave the unit as product. The output of V-103 split to two stream. A stream collected liquid pumped to rerun column as reflux and the rest leave the unit as product after cooling in cooler E-105. The bottom rerun column pumped by P-104 and leaves the unit after Exchanger E-102, air cooled type condenser FA-103 and the cooler E-106.

In general, the stripper overhead is including $\mathrm{nC}_{9}$ or $\mathrm{nC}_{10}$ and lighter materials, while the bottom stream is including $\mathrm{nC}_{10}$ or $\mathrm{nC}_{11}$ and heavier hydrocarbons that fed to rerun column T-102. It is noted in the rerun column, the overhead liquid should contain the range of $\mathrm{nC}_{10}-\mathrm{nC}_{13}$. Finally, the stripper column $\mathrm{T}-101$ and rerun column T-102 are key pieces of equipment in process flow diagram for the pre-distillation unit.

\section{MATHEMATICAL MODEL}

Final design of multistage equipment for the leading to multi-component separations requires severe determina-

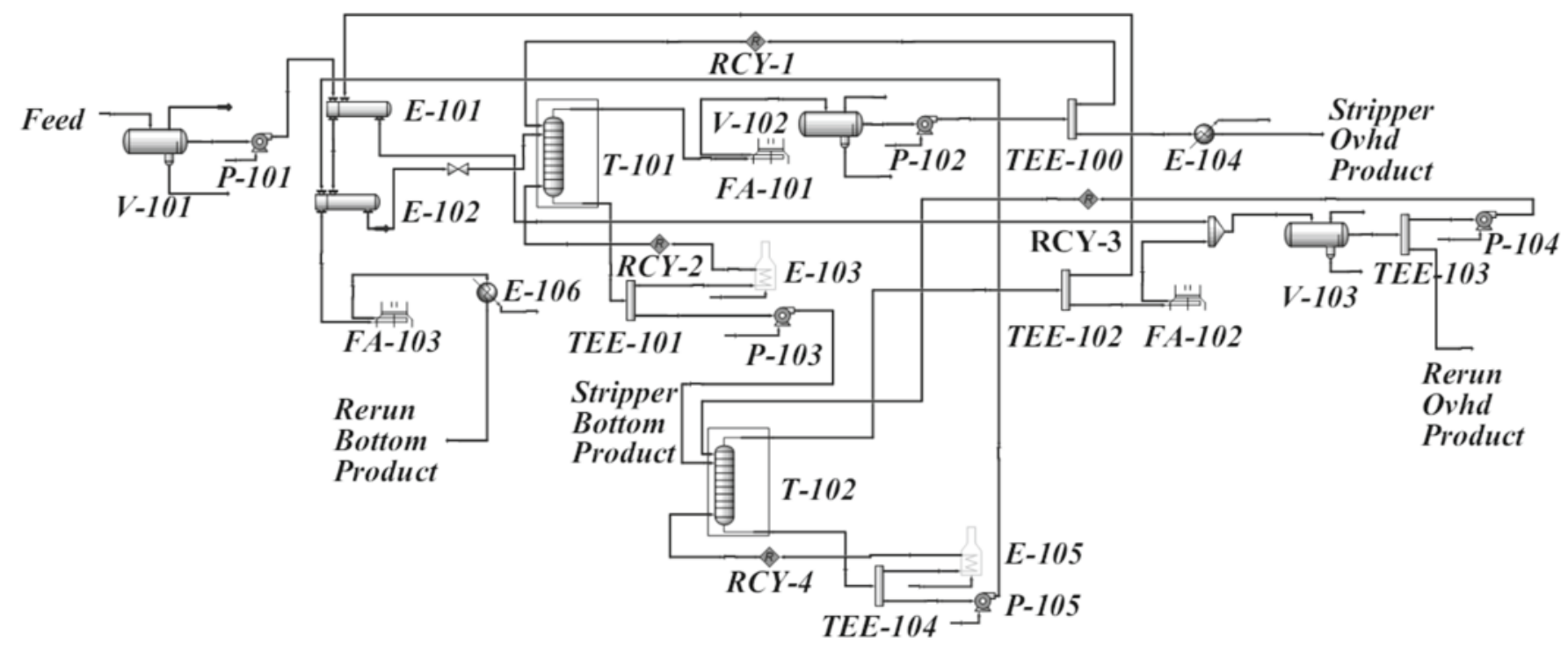

Figure 1. Process flow diagram of pre-distillation unit's simulation 
tion of operating conditions at each stage. However, severe computational procedures may not be justified while multi-component physical properties or stage efficiencies are not well known. This determination is made by solving material balance, energy balance, and equilibrium relations for each stage. Unfortunately, these relations are nonlinear algebraic equations that interact strongly. Thus, the solution procedures are quite difficult and tedious. However, once the procedures are programmed for a high-speed digital computer, solutions are achieved fairly easy and rapid. Such programs are available and widely used. Here it begins with the development of a mathematical model for the equilibrium stage of T-101 and 102 for vapor-liquid contacting. These equations, when collected together for a counter current cascade of stages, are referred to as the MESH equations. A number of methods for solving these equations are mentioned. And finally, based on the type of algorithms for solving distillation model equations and characteristics of this distillation system, a method of convergence is applied using process-simulation program.

Figure 2 shows a schematic diagram of the T-101 distillation model, in which we presume that the fractionating capability of a column is equal to that of $\mathrm{N}$ equilibrium stages. The MESH equations describing one stage of a continuous multi-component distillation are as follows.

Material balance for each component ( $\mathrm{C}$ equations for each stage):

$M=1_{i j}+v_{i j}-v_{i, j+1}-1_{i, j-1}-f_{i, j}=0$

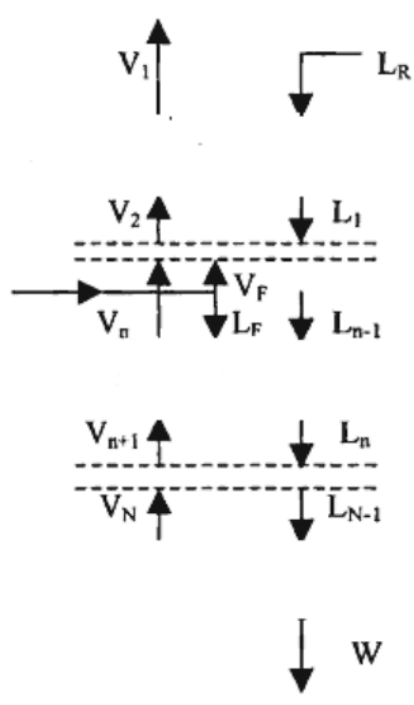

Figure 2. Schematic diagram of T-101 distillation model

$(i=1,2,3, \ldots C ; j=1,2,3, \ldots N)$

Phase equilibrium equations for the compones in each stage are:

$\mathrm{E}_{\mathrm{i}, \mathrm{j}}=\mathrm{y}_{\mathrm{i}, \mathrm{j}}-\mathrm{K}_{\mathrm{i}, \mathrm{i}} \mathrm{x}_{\mathrm{i}, \mathrm{j}}=0$

Mole fraction Summations - S equations (one for each stage):

$$
\begin{aligned}
\left(S_{y}\right)_{j} & =\sum_{i=1}^{c} y_{i, j}-1=0 \\
\left(S_{x}\right)_{j} & =\sum_{i=1}^{c} x_{i, j}-1=0
\end{aligned}
$$

Energy balance $-\mathrm{H}$ equations (one for each stage):

$\mathrm{H}=\mathrm{L}_{\mathrm{j}} \mathrm{h}_{\mathrm{j}}+\mathrm{V}_{\mathrm{j}} \mathrm{H}_{\mathrm{j}}-\mathrm{V}_{\mathrm{j}+1} \mathrm{H}_{\mathrm{j}+1}-\mathrm{L}_{\mathrm{j}-1} \mathrm{~h}_{\mathrm{j}-1}-\mathrm{F}_{\mathrm{j}} \mathrm{h}_{\mathrm{Fj}}-\mathrm{Q}_{\mathrm{j}}=0$

Where

$$
\begin{aligned}
& \mathrm{L}_{\mathrm{j}}=\sum_{\mathrm{i}=1}^{\mathrm{c}} \mathrm{l}_{\mathrm{i}, \mathrm{j}}, \mathrm{V}_{\mathrm{j}}=\sum_{\mathrm{i}=1}^{\mathrm{c}} \mathrm{v}_{\mathrm{i}, \mathrm{j}} \\
& \mathrm{H}_{\mathrm{j}}=\sum_{\mathrm{i}=1}^{\mathrm{c}} \mathrm{H}_{\mathrm{i}, \mathrm{j}}, \mathrm{h}_{\mathrm{j}}=\sum_{\mathrm{i}=1}^{\mathrm{c}} \mathrm{h}_{\mathrm{i}, \mathrm{j}} \mathrm{x}_{\mathrm{ij}}
\end{aligned}
$$

For simplicity, assumed that the vapor phase is ideal, but the liquid phase of the mixture is a non-ideal solution. So the following three equations are necessary for simulation:

$\mathrm{k}_{\mathrm{ij}}=\frac{\gamma_{\mathrm{ij}} \mathrm{p}_{\mathrm{ij}}^{\mathrm{s}}}{\mathrm{p}_{\mathrm{j}}}$

$h_{i j}=h_{i j}\left(T_{j}, p_{j}\right), H_{i j}=H_{i j}\left(T_{j}, p_{j}\right)$

Where the saturated vapor pressure can be calculated by the Antoine equation, activity coefficient $\gamma_{\mathrm{ij}}$, and enthalpy data $h_{i j}, H_{i j}$ are calculated using Peng-Robinson equation, respectively.

The fugacity coefficient has been calculated by Eq. 10 .

$\operatorname{Ln} \emptyset_{i}=-\ln (V-b)+\frac{\bar{b}}{V-b}+\frac{a}{2 \sqrt{2} b} \ln \left(\frac{V+b(1+\sqrt{2})}{V+b(1-\sqrt{2})}\right)\left(-1+\frac{\bar{a}}{a}+\frac{\bar{b}}{b}\right)$

$\overline{\mathrm{a}}=\frac{\partial \mathrm{n}^{2} \mathrm{a}}{\partial \mathrm{n}}, \overline{\mathrm{b}}=\frac{\partial \mathrm{nb}}{\partial \mathrm{n}}$

The volume $\mathrm{V}$ is calculated using $\mathrm{PR}$ equation of state. The parameters $\mathrm{a}$, and $\mathrm{b}$ are calculated from the mixing rules.

The following relation calculates the enthalpy.

$\mathrm{H}-\mathrm{H}^{\mathrm{IG}}=\mathrm{PV}-\mathrm{RT}-\left(\mathrm{a}-\left(\frac{\mathrm{da}}{\mathrm{dT}}\right) \mathrm{T}\right) \frac{1}{2 \sqrt{2} \mathrm{~b}} \ln \left(\frac{\mathrm{V}+\mathrm{b}(1+\sqrt{2})}{\mathrm{V}+\mathrm{b}(1-\sqrt{2})}\right)$

In general, a counter current cascade of $\mathrm{N}$ stages is represented by $\mathrm{N}(2 \mathrm{C}+3)$ simultaneous nonlinear algebraic equation (MESH) including unknown variables $x_{i, j}, y_{i, j}$, $L_{j}, V_{j}$ and $T_{j}$, these set equations must be solved by iterative solution procedures. Among of several techniques cited in literatures ${ }^{\mathbf{1 3}}$ the Newton-Raphson and Inside-Out techniques are the most widely used for solving MESH equations in common simulators (i.e. ASPEN PLUS, CHEMCAD, HYSYS and PRO/II.). Inside-out method produced by Sullivan ${ }^{14}$ is an alternative, robust approach to solve the MESH equations. This method uses an algorithm for solving a tridiagonal-matrix equation, described in literature ${ }^{13}$. In this process-simulation, Inside-Out method is selected using solving settings in software. Simultaneously some adjustable parameters such as Number of Iterations: 300, equilibrium Error Tolerance: $1.0 \mathrm{E}^{-5}$, Heat / Spec Error Tolerance: $5.0 \mathrm{E}^{-4}$ is chosen in solving setting.

\section{Iteration of the process}

A sequential modular approach is chosen to develop the process simulation. The basic idea is that the output variable of the modular units is calculated sequentially and the desired values of the output streams are determined by giving initial streams. As we can see from the process flow diagram of heavy linear paraffins production 
(Fig. 1), RCY-1 and 3 are the recycle streams. In this way RCY-1 and 3 become the input streams of the previous module, but the construct of the module is still to come according to the sequential modular approach. To deal with recycle streams, Upadyhe-Grens proposed the principle of tearing stream. The idea is to specify RCY-1 and 3 with an initial value $\mathrm{z}^{\mathrm{k}}$, by solving a serious unit module calculated value $\mathrm{z}^{\mathrm{k}+1}$, Stripper Bottom Product and Rerun Bottom Product could be obtained. Then $z^{k}$ and $\mathrm{z}^{\mathrm{k}+1}$ are compared, if there is a mismatch, $\mathrm{z}^{\mathrm{k}}$ must be adjusted for them to be in tolerant errors extent. Now the data of Stripper Bottom Product and Rerun Bottom Product is the end results and indicating that the simulation ended.

$\left|\frac{\mathrm{z}^{\mathrm{k}}-\mathrm{z}^{\mathrm{k}+1}}{\mathrm{z}^{\mathrm{k}}}\right| \leq \varepsilon$

Because the structure of T-101 is the same as T-102, the simulation model of $\mathrm{T}-102$ is also similar to that of T-101. Thus, it has made the distillation process model of two column-models directly. First, the parameters of columns design such as feed tray, trays number, tray section sizing such as diameter, space, internal type and so on are fixed in the commercial code using industrial data of LAB plant. Other data requirement for simulation of process flow diagram is adapted with experimental data of pre-distillation unit.

\section{RESULTS AND DISCUSSIONS}

\section{Simulation}

As mentioned previously (Fig. 1) the stripper column T-101 and rerun column T-102 are key devices in process flow diagram for the pre-distillation unit. The data gathered from the manufacturing plant are introduced to run the simulation steps. Table 3 and 4 shows the main and secondary parameters of the actual data from the plant. Also, to prove the accuracy of the simulation, the actual data are used to optimize and prove the sub-models after the establishment of the heavy linear paraffins production process. After simulation of the synthesized flowsheet with a computer-aided simulation package, specific characteristics of the column T-101 and rerun column T-102 and their streams are determined. The comparison between the calculated and the actual values of significant operating conditions (outlet streams of columns) are listed in Table 5. The simulation results are compared with the actual data to verify the reliability of the simulation. As the comparison results show, the selection of columns model, system parameter and simulation module could acceptable predict the behavior of the main unit process. Alternative ways are developed and sensitivity analysis is carried out to specify the effects of varying the initial design specification.

Table 3. The main parameters used in the simulation of the manufacturing plant

\begin{tabular}{|l|c|c|}
\hline Feed stream & T-101 (Stripper Column) & T-102 (Rerun Column) \\
\hline Temperature: $33^{\circ} \mathrm{C}$ & Number of Stages: 55 & Number of Stages: 61 \\
\hline Pressure: $118.4 \mathrm{KPa}$ & Feed Tray: 31 & Feed Tray: 32 \\
\hline Flow Rate: $162 \mathrm{~m}^{3} \cdot \mathrm{hr}^{-1}$ & Feed Temperature: $194{ }^{\circ} \mathrm{C}$ & FA-102 Temperature: $195{ }^{\circ} \mathrm{C}$ \\
\hline $\mathrm{M}_{\mathrm{w}}: 168.3 \mathrm{~kg} / \mathrm{kg} \mathrm{mole}$ & FA-101 Temperature: $67{ }^{\circ} \mathrm{C}$ & Reflux Rate: $173 \mathrm{~m}^{3} \cdot \mathrm{hr}^{-1}$ \\
\hline Std Ideal Density: $804.5 \mathrm{~kg} / \mathrm{m}^{3}$ & Bottom Flow Rate: $145 \mathrm{~m}^{3} \cdot \mathrm{hr}^{-1}$ & Bottom Flow Rate: $35 \mathrm{~m}^{3} \cdot \mathrm{hr}^{-1}$ \\
\hline $\begin{array}{l}\text { Feed Composition: } \\
\text { Table } 1 \text { and } 2\end{array}$ & Reflux Rate: $65 \mathrm{~m}^{3} \cdot \mathrm{hr}^{-1}$ & Sieve Tray Dimensions: \\
\cline { 2 - 3 } & Sieve Tray Dimensions: & Space: $0.55 \mathrm{~m}$, Diameter: $1.5 \mathrm{~m}$ \\
& Space: $0.55 \mathrm{~m}$, Diameter: $1.5 \mathrm{~m}$ & \\
\end{tabular}

Table 4. The general secondary parameters used in the simulation of the manufacturing plant

\begin{tabular}{|l|c|c|}
\hline P-101 & E-101 (Shell \& Tube Type ) & E-102 (Shell \& Tube Type) \\
\hline Delta P: $360.3 \mathrm{KPa}$ & Tube Outlet Temp.: $185^{\circ} \mathrm{C}$ & Tube Outlet Temp.: $212^{\circ} \mathrm{C}$ \\
\hline$P-102$ & Shell Outlet Temp.: $194^{\circ} \mathrm{C}$ & Pressure Drop: $100 \mathrm{KPa}$ \\
\hline Delta P: $536.0 \mathrm{KPa}$ & Pressure Drop: $100 \mathrm{KPa}$ & E-106 (Cooler Type) \\
\hline$P-103$ & $E-104$ (Cooler Type) & Outlet Temp.: $43^{\circ} \mathrm{C}$ \\
\hline Delta P: $283.7 \mathrm{KPa}$ & Outlet Temp.: $38^{\circ} \mathrm{C}$ & FA-103 (Air Cooler) \\
\hline$P-104$ & $P-105$ & Outlet Temp: \\
\hline Delta P: $635.6 \mathrm{KPa}$ & Delta P: $637.4 \mathrm{KPa}$ & $208^{\circ} \mathrm{C}$ \\
\hline
\end{tabular}

Table 5. Comparison of simulation results of T-101,102 with actual data in LAB plant

\begin{tabular}{|c|c|c|c|c|}
\hline Streams & Data Type & $\begin{array}{l}\text { Actual } \\
\text { Data }\end{array}$ & $\begin{array}{c}\text { Simulation } \\
\text { Data }\end{array}$ & $\begin{array}{c}\text { Relative } \\
\text { Error [\%] }\end{array}$ \\
\hline $\begin{array}{l}\text { Rerun Ovhd } \\
\text { Product }\end{array}$ & $\begin{array}{l}\text { Molecular Weight } \\
\text { Std. Ideal Liq. Density }\left[\mathrm{kg} / \mathrm{m}^{3}\right] \\
\text { Distillate Rate }\left[\mathrm{m}^{3} / \mathrm{hr}\right] \\
\mathrm{nC}_{10}-\mathrm{nC}_{13}[\mathrm{~kg} / \mathrm{hr}]\end{array}$ & $\begin{array}{c}166 \\
799.1 \\
108 \\
19440\end{array}$ & $\begin{array}{r}167.5 \\
791.0 \\
109.9 \\
20357.2\end{array}$ & $\begin{array}{l}+0.9 \\
-1.01 \\
+1.73 \\
+4.50\end{array}$ \\
\hline $\begin{array}{l}\text { Rerun Bottom } \\
\text { Product }\end{array}$ & $\begin{array}{l}\text { Molecular Weight } \\
\text { Std. Ideal Liq. Density }\left[\mathrm{kg} / \mathrm{m}^{3}\right] \\
\mathrm{nC}_{14}-\mathrm{nC}_{16}[\mathrm{~kg} / \mathrm{hr}]\end{array}$ & $\begin{array}{r}204.7 \\
824.4 \\
8051.7 \\
\end{array}$ & $\begin{array}{c}204.2 \\
807.7 \\
7964.17\end{array}$ & $\begin{array}{l}-0.24 \\
-2.03 \\
-1.09 \\
\end{array}$ \\
\hline $\begin{array}{l}\text { Stripper Ovhd } \\
\text { Product }\end{array}$ & $\begin{array}{l}\text { Molecular Weight } \\
\text { Std. Ideal Liq. Density }\left[\mathrm{kg} / \mathrm{m}^{3}\right] \\
\text { Distillate Rate }\left[\mathrm{m}^{3} / \mathrm{hr}\right]\end{array}$ & $\begin{array}{c}134 \\
757.5 \\
17 \\
\end{array}$ & $\begin{array}{l}127.9 \\
758.7 \\
17.12\end{array}$ & $\begin{array}{l}-4.55 \\
+0.16 \\
-0.7\end{array}$ \\
\hline $\begin{array}{l}\text { Stripper Column } \\
{[\mathrm{T}-101]}\end{array}$ & $\begin{array}{l}\text { Tray } 1 \text { temperature }(\mathrm{Ovhd})\left[{ }^{\circ} \mathrm{C}\right] \\
\text { Tray } 55 \text { temperature }(\text { Bottom })\left[{ }^{\circ} \mathrm{C}\right]\end{array}$ & $\begin{array}{l}162 \\
240\end{array}$ & $\begin{array}{l}163.9 \\
234\end{array}$ & $\begin{array}{l}+1.16 \\
-2.5\end{array}$ \\
\hline
\end{tabular}




\section{Sensitivity analysis of operating parameters}

The whole distillation unit can be simulated on Aspen HYSYS platform to improve the process performance and maximize the process profitability. The reflux ratio influences both the separation performance and the economical efficiency in distillation columns. The reflux ratio is dependent on condenser and re-boiler load. However, reflux ratio is adjusted to control the composition of components in top product. As the amount of reflux ratio is changed, the temperature profile and hence tray composition of the column will be changed. After sensitivity analyses of the process variables, reflux rate and its temperature of T-101 and T-102 are considered as key variables to influence the process performance such as cutting heavy paraffin flow and energy duty. The feedstock conditions that fed to stripper column T-101 and rerun bottom product cannot be changed due to the heat exchanger E-101, 102 technology. The compositions at the bottom and the top of the columns were used as the constraint conditions. A multi-objective function was defined for column-101 and minimized based on: 1) flow rates of cuttings $\mathrm{nC}_{11}-\mathrm{nC}_{16}$ and $\mathrm{nC}_{5}-\mathrm{nC}_{9}$ in overhead and bottom streams respectively, 2) total heat duties of FA-101 and re-boiler E-103 while for column-102, the multi-objective function was defined and maximized and minimized based on the flow rates of cuttings $\mathrm{nC}_{11}-\mathrm{nC}_{13}$ and $\mathrm{C}_{14}-\mathrm{nC}_{16}$ in overhead streams, respectively. The analyses were carried out using gradient search (GS) technique developed in commercial code platform.

a) Figure 3 shows the effects of reflux rate of T-101 on total heat duty (condenser 101 and re-boiler E-103) at different reboil rates of column. The optimal reflux rate to achieve minimizes duty varied and found to lie between 46 and $64 \mathrm{~m}^{3} / \mathrm{hr}$.

b) For the case of overhead and bottom streams of $\mathrm{T}-101$, the variation of reflux rate on total flow rate of $\mathrm{nC}_{11}-\mathrm{nC}_{16}$ in overhead and $\mathrm{nC}_{5}-\mathrm{nC}_{9}$ in bottom at different

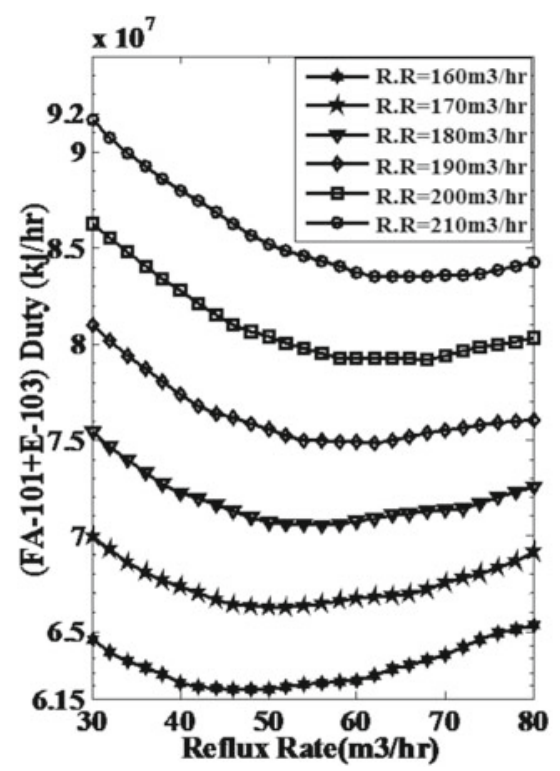

Figure 3. Effects of reflux rate on total heat duty in stripper column

reboil rates were evaluated (Figure 4 and 5). The results indicate that increasing of reflux rate deal to decreasing of cutting $\mathrm{nC}_{11}-\mathrm{nC}_{16}$ in overhead stream while this situation deal with increasing in cutting of $\mathrm{nC}_{5}-\mathrm{nC}_{9}$ in bottom

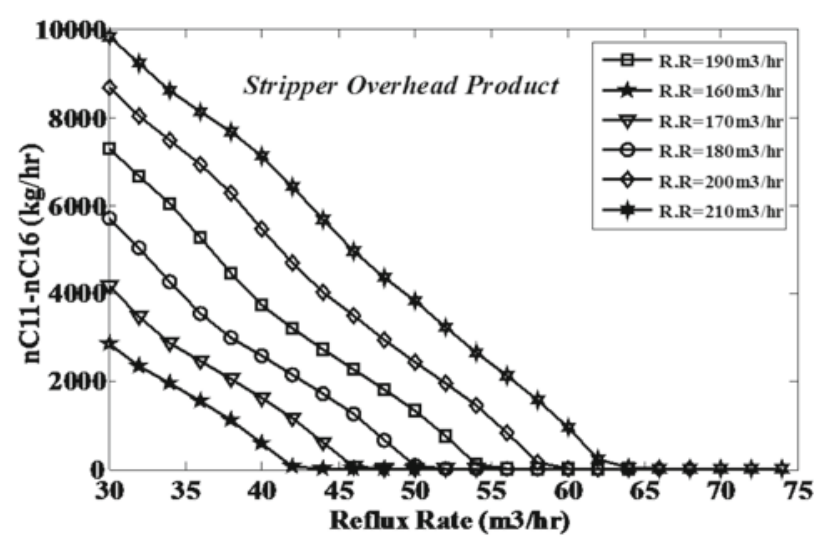

Figure 4. Effects of reflux rate on undesirable flow rate in stripper overhead product

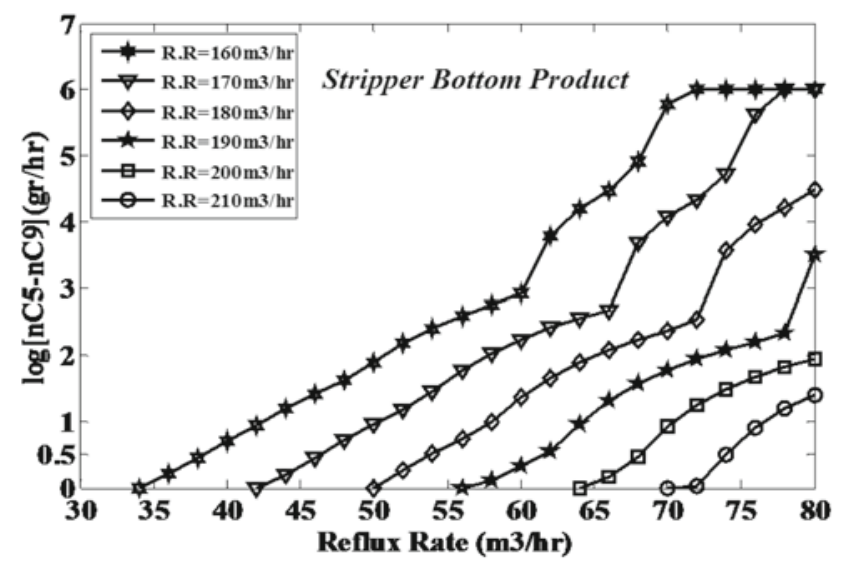

Figure 5. Effects of reflux rate on undesirable flow rate in stripper bottom product

stream (Fig. 5). It is mentioned that the value of reboil rate in which column operated is $190 \mathrm{~m}^{3} / \mathrm{hr}$. Therefore, the optimal reflux rate to achieve minimizes of cutting $\mathrm{nC}_{11}-\mathrm{nC}_{16}$ in overhead stream lie between 60 to $64 \mathrm{~m}^{3} /$ hr. As shown in Figure 5 the lower value of cutting $\mathrm{nC}_{5}-\mathrm{nC}_{9}$ in bottom stream was obtained in reflux rate close to $55 \mathrm{~m}^{3} / \mathrm{hr}$. In addition the increase amount of $\mathrm{C}_{10}$ in bottom stream can improve the LAB production. Figure 6 indicates that when the reflux rate increases the amount of $\mathrm{C}_{10}$ also increase to extremely limit $3.3 \mathrm{~kg}$ / $\mathrm{hr}$. It is noted more increase in amount of $\mathrm{C}_{10}$ caused to the increase of undesirable of $\mathrm{C}_{9}$ in bottom stream. Reflux temperature is significance variable in quality

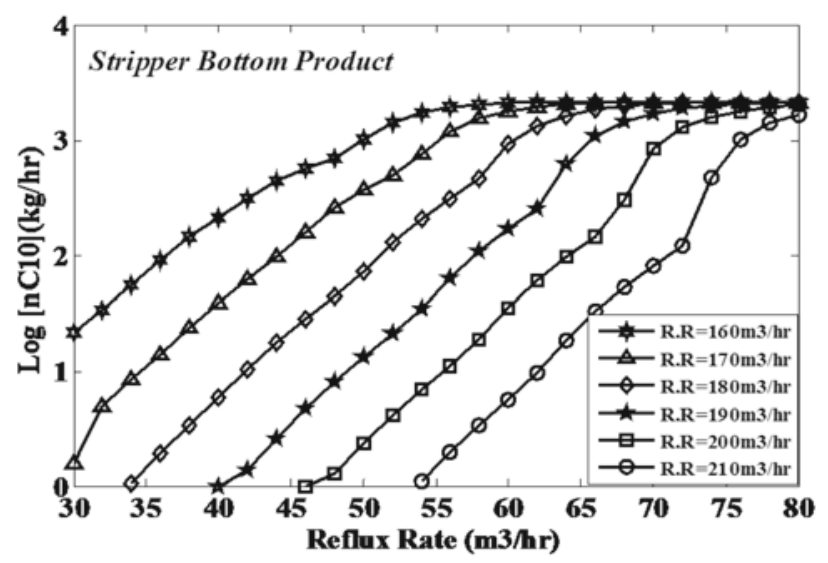

Figure 6. Effects of reflux rate on $\mathrm{nC}_{10}$ flow rate in stripper bottom product 
of outlet streams. In Figure 7 for reducing amount of cutting $\mathrm{nC}_{11}-\mathrm{nC}_{16}$ in overhead, the reflux should be kept at sub-cooled liquid.

Also, the effect of reflux rate of rerun column T-102 on flow rates of cutting $\mathrm{nC}_{11}-\mathrm{nC}_{13}$ and $\mathrm{nC}_{14}-\mathrm{nC}_{16}$ shown in Figures 8 and 9, respectively. As seen from Figure

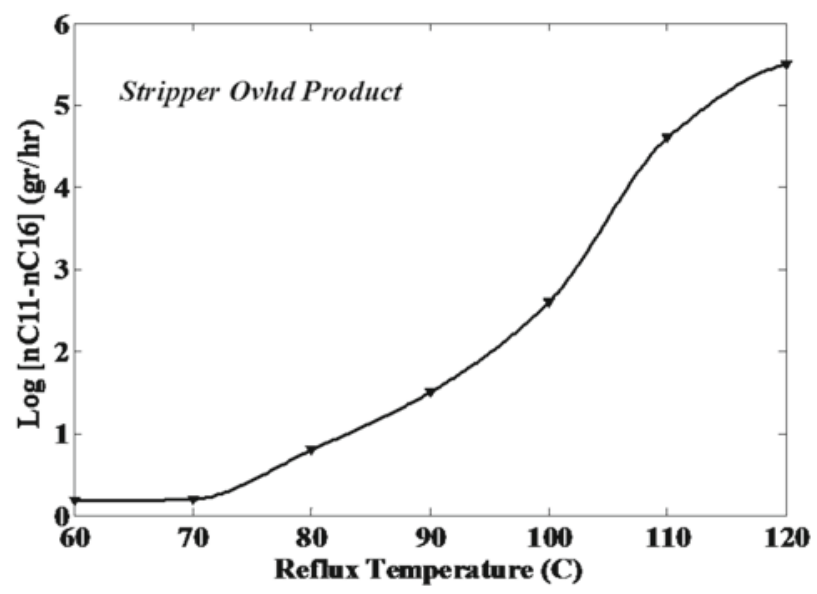

Figure 7. Effects of reflux temperature on undesirable flow rate in stripper overhead product

8 , flow of cutting $\mathrm{nC}_{11}-\mathrm{nC}_{13}$ not changed with increasing reflux rate close to $180 \mathrm{~m}^{3} / \mathrm{hr}$. Although more increasing in reflux rate showed a sharp declining in flow of $\mathrm{nC}_{11}$ $-\mathrm{nC}_{13}$. Moreover, it can be seen from Figure 9 that there is a significant relationship between the reflux rate and flow rate of $\mathrm{nC}_{14}-\mathrm{nC}_{16}$. However, the optimal reflux rate is close to $170 \mathrm{~m}^{3} / \mathrm{hr}$ for remaining of $\mathrm{nC}_{11}-\mathrm{nC}_{13}$ in higher and $\mathrm{nC}_{14}-\mathrm{nC}_{16}$ in lower flow rates.

Figure 10 shows the effects of reflux temperature on flow rate of cutting of $\mathrm{nC}_{11}-\mathrm{nC}_{13}$ in overhead. The result show that to achieve a suitable condition, the tempera-

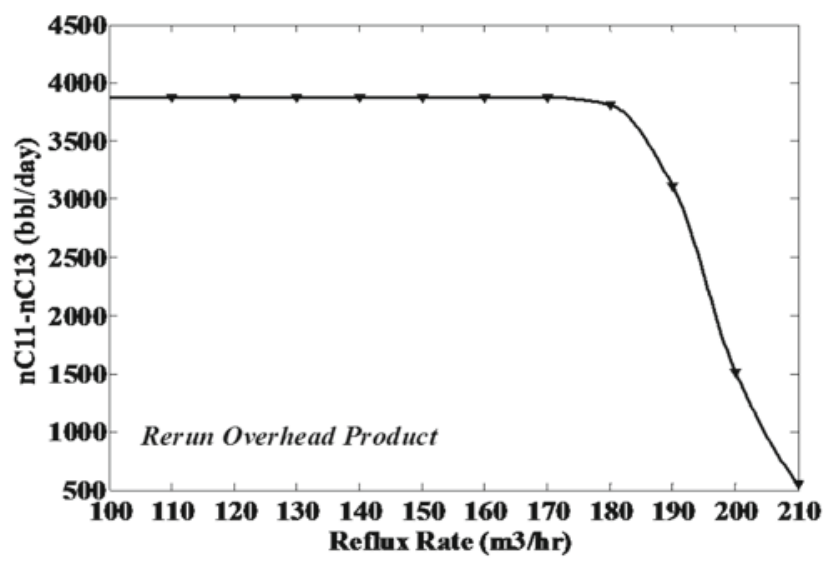

Figure 8. Effects of reflux rate on desirable flow rate in rerun overhead product

ture should be kept saturated liquid. This carried out using condenser FA-102. The heat duty of condenser 102 achieve to saturated liquid temperature shown in Figure 11. Result in; condenser temperature should be kept at $200^{\circ} \mathrm{C}$.

In column T-102, optimum feed stage is determined using minimized total heat duty. The influence of the feed tray number on total duty of condenser 102 and reboiler

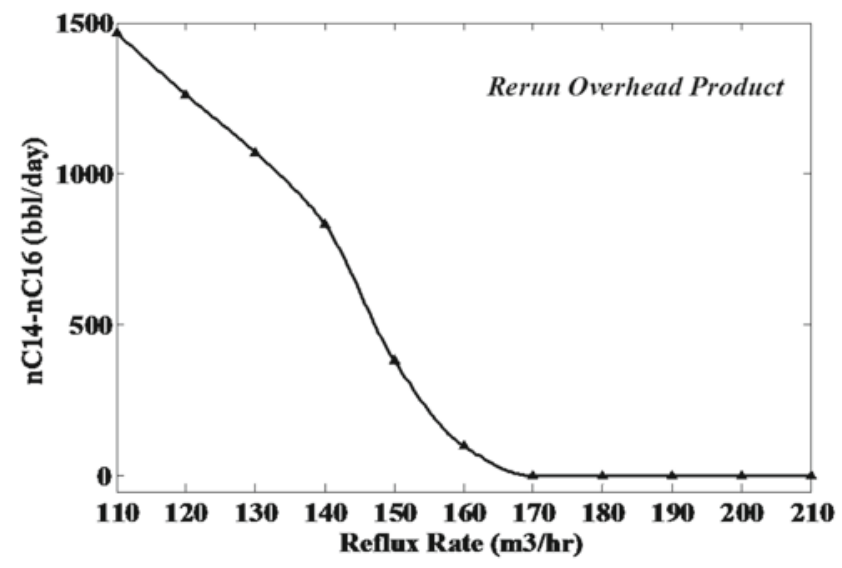

Figure 9. Effects of reflux rate on undesirable flow rate in rerun overhead product

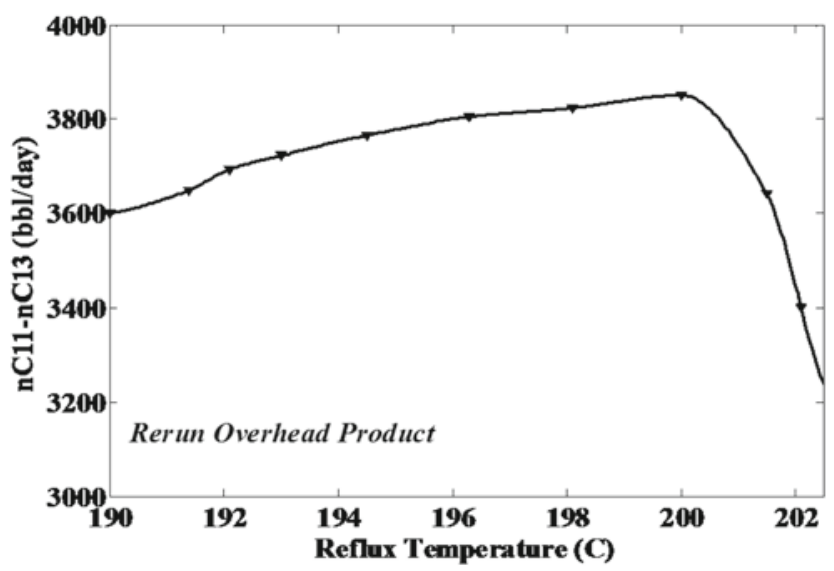

Figure 10. Effects of reflux temperature on desirable flow rate in rerun overhead product

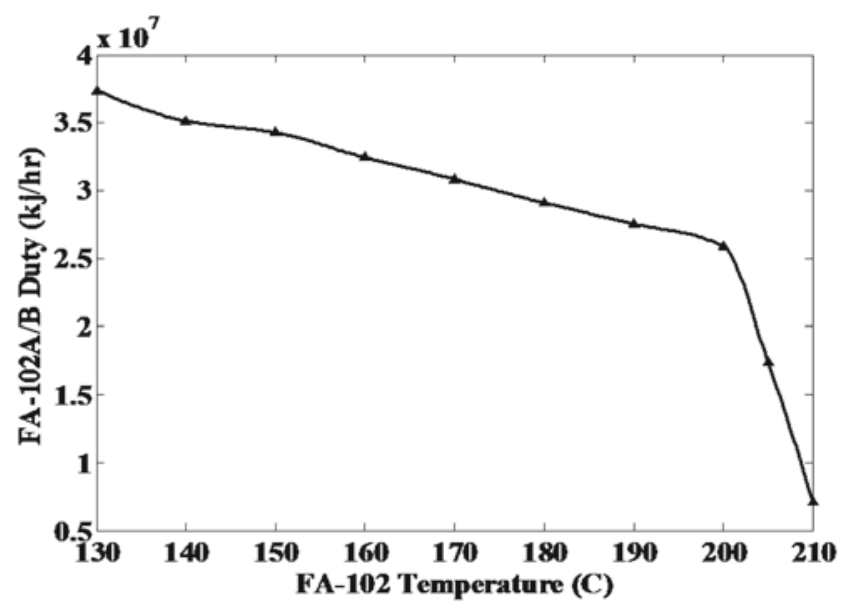

Figure 11. Effects of total condenser temperature on heat duty in rerun overhead column

E-105 is presented in Figure 12, in which the minimum duty is obtained in feed tray number 30 . Similarly, in column 101, total minimum heat duty (condenser 101 and reboiler E-103) is obtained in feed stage number 31.

These cases show the usefulness of simulation results to predict variables of interest in industrial scales processes. Once the process is modeled in commercial simulators any variable can be changed to see how the rest of the process will vary and will affect quality and quantity of the final desirable products. 


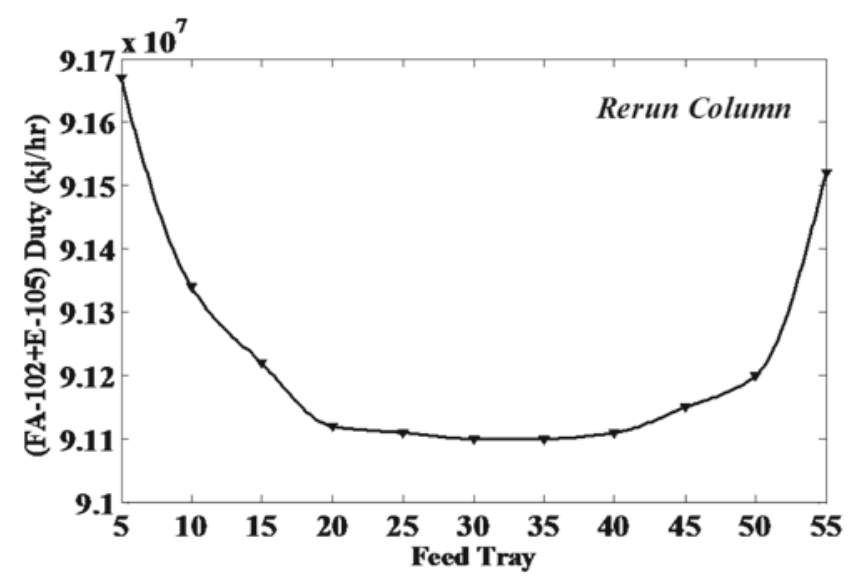

Figure 12. Effect of feed stage location on total heat duty

\section{CONCLUSIONS}

In this paper, the pre-distillation process of LAB plant was investigated thoroughly. From the viewpoint of separating heavy paraffins (range $\mathrm{C}_{10}-\mathrm{C}_{13}$ ) in high composition, Aspen HYSYS was applied to obtain the design parameters of the columns. The summary of the main remarks can be obtained as follows:

1 - The results are showed that estimated results by process-simulation are in good agreement with outputs of pre-distillation unit. Therefore, the outputs of the models approach are precise and reliable.

2 - The analyses were carried out using gradient search (GS) technique regarding to multi-objective functions. Finally, in stripper column T-101 and rerun column T-102, with regarding extant limitations, optimum reflux rate are $64 \mathrm{~m}^{3} / \mathrm{hr}$ and $170 \mathrm{~m}^{3} / \mathrm{hr}$, respectively. Also, optimum reflux temperatures are obtained in $70^{\circ} \mathrm{C}$ and $200^{\circ} \mathrm{C}$, respectively. Results show that the state of fluid in total condensers of stripper and rerun columns should be kept sub-cooled and saturated liquid, respectively.

3 - Decreasing the loss of $\mathrm{nC}_{10}-\mathrm{C}_{13}$ in the distillate of $\mathrm{T}-101$ and increasing the output of the regular $\mathrm{nC}_{10}-\mathrm{C}_{13}$ product of T-102.

The results in this paper are based solely on simulation, and the optimal conditions obtained will soon be applied to the corresponding industrial plant.

\section{ACKNOWLEDGMENT}

The authors would grateful of process experts in pre-distillation unit of Isfahan Chemical Industrial (ICI complex is a typical of LAB plant).

\section{NOMENCLATURE}

$\mathrm{f}_{\mathrm{ij}} \quad-$ Flow rate at which component $\mathrm{i}$ in the feed stream enters the jth stage $[\mathrm{kg} / \mathrm{hr}]$

$\mathrm{F}_{\mathrm{j}} \quad$ - Total flow rate of a feed stream entering the jth stage $[\mathrm{kg} / \mathrm{hr}]$

$\mathrm{F} \quad-$ Feed stream flow rate $[\mathrm{kg} / \mathrm{hr}]$

$\mathrm{h}_{\mathrm{Fj}} \quad-$ Total enthalpy of a feed stream entering the jth stage $[\mathrm{kj} / \mathrm{kg}]$

$h_{i j} \quad-$ Enthalpy of a liquid stream for component $\mathrm{i}$ on the jth stage $[\mathrm{kj} / \mathrm{kg}]$

$h_{j} \quad-$ Total enthalpy of a liquid stream on the jth stage $[\mathrm{kj} / \mathrm{kg}]$
$\mathrm{H}_{\mathrm{ij}} \quad-$ Enthalpy of a vapor stream for component $\mathrm{i}$ on the jth stage $[\mathrm{kj} / \mathrm{kg}]$

$\mathrm{H}_{\mathrm{j}} \quad-$ Total enthalpy of a vapor stream on the jth stage $[\mathrm{kj} / \mathrm{kg}]$

$\mathrm{K}_{\mathrm{ij}} \quad$ - Vapor-liquid equilibrium ratio for component i on the jth stage

$\mathrm{l}_{\mathrm{ij}} \quad-$ Flow rate at which component $\mathrm{i}$ in the liquid phase leaves the jth stage $[\mathrm{kg} / \mathrm{hr}]$

$\mathrm{L}_{\mathrm{j}} \quad-$ Total flow rate of a liquid stream on the jth stage $[\mathrm{kg} / \mathrm{hr}]$

$\mathrm{p}_{\mathrm{ij}}^{\mathrm{s}} \quad$ - Saturated vapor pressure of component $\mathrm{i}$ on the jth stage under $\mathrm{T}_{\mathrm{j}}[\mathrm{mmHg}]$

$\mathrm{Q}_{\mathrm{j}} \quad-$ Rate of external heat input to the $\mathrm{jth}$ stage $[\mathrm{kj} / \mathrm{hr}]$

$\mathrm{T}_{\mathrm{j}} \quad-$ Temperature of the $\mathrm{jth}$ stage $\left[{ }^{\mathrm{O}} \mathrm{K}\right]$

$\mathrm{T}_{\mathrm{w}} \quad-$ Wall temperature [K]

$v_{\mathrm{ij}} \quad-$ Flow rate at which component $\mathrm{i}$ in the vapor phase leaves the jth stage $[\mathrm{kg} / \mathrm{hr}]$

$\mathrm{V}_{\mathrm{j}} \quad$ - Total flow rate of a vapor stream on the jth stage $[\mathrm{kg} / \mathrm{hr}]$

W - Total flow rate of the bottom product [ $\mathrm{kg} / \mathrm{hr}]$

$\mathrm{x}_{\mathrm{ij}}-$ Liquid mole fraction of component $\mathrm{i}$ on the jth stage

$y_{i j} \quad-$ Vapor mole fraction of component $i$ on the jth stage

$\mathrm{L}_{\mathrm{R}} \quad-$ Reflux flow rate $[\mathrm{kg} / \mathrm{hr}]$

$\mathrm{V}_{\mathrm{n}} \quad-$ Total flow rate of a vapor stream on the nth stage $[\mathrm{kg} / \mathrm{hr}]$

$\mathrm{L}_{\mathrm{n}} \quad-$ Total flow rate of a Liquid stream on the nth stage $[\mathrm{kg} / \mathrm{hr}]$

$\gamma_{\mathrm{ij}} \quad-$ Activity coefficient of component $\mathrm{i}$ on the jth stage

\section{Subscripts}

I - component number (1 to $\mathrm{C}$ )

$\mathrm{J} \quad-$ stage number (1 to $\mathrm{N}$ )

\section{Abbreviations}

PR - Peng-Robinson

T $\quad-$ Tower

E - Exchanger

P $\quad-$ Pump

V - - Vessel

RCY - Recycle

Ovhd - Overhead

R.R - Reboil Rate

bbl/day - barrels per day

\section{LITERATURE CITED}

1. Zahedi, G., Yaqubi, H. \& Ba-Shammakh, M. (2009). Dynamic modeling and simulation of heavy paraffin dehydrogenation reactor for selective olefin production in linear alkyl benzene production plant. Appl. Catal. A. 358 (1), 1-6. DOI: 10.1016/j.apcata.2009.01.043.

2. Bahasin, M.M., McCain, J.H., Vora, B.V., Imai, T. \& Pujado, P.R. (2001). Dehydrogenation and oxydehydrogenation of paraffins to olefins. Appl. Catal. A. 221 (1-2), 397-419. DOI: 10.1016/s0926-860x(01)00816-x.

3. Kocal, J.A., Vora, B.V. \& Imati, T. (2001). Production of Linear alkylbenzenes. Appl. Catal. A. 221 (1-2), 295. DOI: 10.1016/s0926-860x(01)00808-0.

4. Yangyou, H., Hongye, S., Jingwei, L., Shengjing, M., Jian, C. \& Jun, W. (2002). Simulation and Optimization of Linear 
Alkylbenzenes Distillation Process. Dev. Chem. Eng. Mineral Process. 10, 33-45. DOI: 10.1002/apj.5500100104.

5. Dolganova, I.O., Dolganov, I.M., Ivashkina, E.N., Ivanchina, E.D. \& Romanovskiy, R.V. (2012). Development of approach to modeling and optimization of non-stationary catalytic processes in oil refining and petrochemistry. Pol. J. Chem. Tech. 14 (4), 22-29. DOI: 10.2478/v10026-012-0097-y.

6. Bhutani, N., Ray, A.K. \& Rangaiah, G.P. (2006). Modeling, simulation, and multi-objective optimization of an industrial hydro-cracking unit. Ind. Eng. Chem. Res. 45 (4), 1354-1372. DOI: 10.1021/ie050423f.

7. More, R.K., Bulasara, V.K., Uppaluri, R. \& Banjara, V.R. (2010). Optimization of crude distillation system using aspen plus: Effect of binary feed selection on grass-root design. Chem. Eng. Res. Design. 88 (2), 121-134. DOI: 10.1016/j. cherd.2009.08.004.

8. Lei, Z., Yi, C. \& Yang., B. (2013). Design, optimization, and control of reactive distillation column for synthesis of tertamyl ethyl ether. Chem. Eng. Res. Design. 91 (5), 819-830. DOI: 10.1016/j.cherd.2012.08.013.

9. Bai, Z., Ma, H., Zhang, H., Ying, W. \& Fang, D. (2013). Process simulation of dimethyl ether synthesis via methanol vapor phase dehydration. Pol. J. Chem. Tech. 15 (2), 122-127. DOI: $10.2478 /$ pjct-2013-0034.

10. Askari, A., Karimi, H., Rahimi, M.R. \& Ghanbari, M. (2012). Simulation and modeling of catalytic reforming process. Petrol. Coal. 54 (1), 76-84.

11. West, A.H., Posarac, D. \& Ellis, N. (2008). Assessment of four biodiesel production processes using HYSYS Plant, Bioresour. Technol. 99 (4), 6587-6601. DOI: 10.1016/j.biortech.2007.11.046.

12. Agarwal, M., Singh, K. \& Chaurasia S.P. (2012). Simulation \& sensitivity analysis for biodiesel production in a reactive distillation column. Pol. J. Chem. Tech. 14 (3), 59-65. DOI: 10.2478/v10026-012-0085-2.

13. Seader, J.D. \& Henley Ernest, J. (2006). separation process principles, $2^{\text {nd }}$ edition, John Wiley \& Sons, Inc., Hoboken.

14. Boston, J.F. \& Sullivan, S.L. (1974). A new class of solution methods for multi components, multistage separation processes. Can. J. Chem. Eng. 52 (1), 52-63. DOI: 10.1002/ cjce. 5450520108 . 